\title{
Synthesis, Characterization and Biological Evaluation of 3'-Benzoyl-5'- (Furan-2-yl)-4'-Phenylspiro[Indoline-3,2'-Pyrrolidin]-2-One Derivatives and its Molecular Docking Studies
}

\author{
D. Rajaraman ${ }^{1, a}$, M. Arockia Doss ${ }^{1}$, K. Krishnasamy ${ }^{2, b,{ }^{*}}$ \\ ${ }^{1}$ Department of Chemistry, St Joseph University, Dimapur - 797 115. Nagaland, India. \\ ${ }^{2}$ Department of Chemistry, Annamalai University, Annamalainagar 608 002, Tamil Nadu, India. \\ aRajaraman4389@gmail.com, brishnasamybala56@gmail.com
}

Keywords: Spirooxindole, Antibacterial, Antifungal, Molecular Docking.

\begin{abstract}
A series of new spirooxindole derivatives were synthesized via 1,3-dipolar cycloaddition. All the synthesized compounds were evaluated for antimicrobial activity. In antibacterial studies compound $\mathbf{4 d}$ demonstrated the most potent inhibitory activity (MIC = $12.5 \mathrm{lg} / \mathrm{mL}$ for K.pneumonia, B.cereus and S.typhi), which was compared with the positive control streptomycin. In antifungal studies compound $4 \mathbf{e}$ demonstrated the most potent inhibitory activity $(\mathrm{MIC}=3.125 \mathrm{lg} / \mathrm{mL}$ for C.albicans and A.niger), which was related with the standard drug ketaconazole. In addition, molecular modeling studies were also performed to disclose the binding modes of the most active inhibitors to the amino acid residues that compose the active site of the glucosamine-6-phosphate synthase and crystal structure of human lanosterol 14-alpha dimethylase in complex with ketaconazole enzyme.
\end{abstract}

\section{Introduction}

Examining new bioactive promoters with the unimportant wide arrangement of built steps and in significantly less time is a first rate dare to the researchers [1]. In any case, physicists have opposed some other mission as far back as a long time in growing new techniques that are green, specific and over the top yielding furthermore environmentally liberal. In doubtlessly comprehended, the standard techniques incorporate the usage of multistep reaction groupings which had been associated with low yields, absurd cost and inconvenience within the disconnection of the stock. The use of multicomponent reactions (MCRs) has create as a present strategy which includes three or extra straightforward and versatile particles united to rapidly introduce assistant multifaceted nature and grouping, and offers sizable preferences over traditional direct sort union [2]. Spirooxindoles are seen to have a wide arrangement of regular activities, which fuses antimicrobial and antitumor, despite inhibitors of the human NKI receptor. Particularly, spirooxindolepyrrolidine cross breed particles display neighborhood pain relieving results [3]. Despite this, spirotryprostatin has antimitotic houses with one of the little molecules, MDM2, in preclinical change. As of late spirooxindole-pyrrolidine creamer particles have been exhibited to have promising against TB relaxation movement $[4,5]$. In light of the expansive natural activities of these irritates, the mix of these iotas is a district of consistent studies. In classy, isatin and auxiliaries are used as starting substances to guide 1,3-dipolar cycloadditions to yield spirooxindole focus structures.[6] In perspective of the ease of rule, the imines created from isatin with an amino acids or amines are reliably picked as huge 1,3-dipolar intermediates to react with specific dipolarophiles, for example, $\beta$-nitro styrenes, $\alpha, \beta$-unsaturated esters, dienones, $\alpha, \beta$ - unsaturated ketones, novel strong inhibitors of cutting edge glycation final item and electron-poor alkenes [7, 11]. A weighty part of the thought about 1,3-dipolar cycloadditions, $\beta$-nitrostyrenes are the most broadly used dipolarophiles, in light of their application as suitable dipolarophiles for 1,3-dipolar cycloaddition reactions to get prepared spirooxindoles. Chen and associates communicated their revelations within the 1,3-dipolar cycloaddition reactions of isatin, an amino acids and bnitrostyrenes with emerge regioselectivity [12]. Perumal and partners said 1,3-dipolar cycloaddition reactions of isatin, phenylglycine/proline/thiaproline with $\beta$-nitrostyrenes and surveyed those blends 
for their in vitro activity towards Mycobacterium tuberculosis H37Rv (MTB) [13]. Finally, PengFei $\mathrm{Xu}$ and partners suggested that an uneven 1,3-dipolar cycloaddition reaction of isatin, benzyl amine and $\beta$ - nitrostyrenes with suitable selectivity in exceptional yield joins using steeplyesteemed chiral driving forces [14]. There's no fundamental system for the mix of spirooxindoles conveyed by the aggregate of benzyl amine, isatin and $\beta$-nitrostyrenes. Inferable from the natural significance of this tastefulness of blends, there is a need to add to a capable, fresh and speedy technique to overhaul the library of spirooxindoles. On this endeavor to get entry to the library of blends containing both spirooxindoles and pyrrolidine studs, we found the congruity of a microwave (MW) light approach to manage add to a gainful, supportive, over the top yield and quick fresh tradition.[15] In latest years, more highlight has been given to developing basic and fresh traditions for the mix of various trademark blends. Despite this, examination is in like way focused at the reaction in watery media as a result of precise homes like arranged openness, nonhurtful nature and wellbeing in overseeing.

\section{Experimental}

\section{General method}

All the reported melting points were taken in open capillaries and are uncorrected. IR spectra were recorded in AVATAR-330 FT-IR spectrophotometer (Thermo Nicolet) and only noteworthy absorption levels (reciprocal centimeters) are listed. The ${ }^{1} \mathrm{H}$ and ${ }^{13} \mathrm{C}$ NMR spectra at 400 and $100 \mathrm{MHz}$, respectively were obtained at room temperature using a Bruker $400 \mathrm{MHz} \mathrm{NMR}$ spectrometer (Bruker biospin, California, USA).

General procedure for the synthesis of 3-benzoyl-5-(furan-2-yl)-4-phenylspiro [indoline-3,2pyrrolidin]-2-one derivatives (4a-g)

An oven-dried hip flask was chilled under a stream of nitrogen and stimulating with a mixture of chalcones $(1.0 \mathrm{mmol})$, isatin $(1.0 \mathrm{mmol})$, furfuryl amine $(1.0 \mathrm{mmol})$ in methanol $(20 \mathrm{ml})$. The mixture was refluxed until the vanishing of the preliminary materials as evidenced by the TLC (Scheme 2). After the reaction was over, the solvent was removed in vacuo and the residue was chromatographed on silica gel using hexane-ethyl acetate (7:3) as eluent to give the cycloadducts (4a-g) in tremendous yields.

\section{Molecular Docking Study}

Molecular docking experiment was carried out to study the exact binding location of ligand on protein. Molecular docking simulation was performed with the Argus Lab 4.0.1. The prepared 3D structures of 2VF5 and 3LD6 protein was downloaded from the protein data bank (see http// www.rcsb.org/pdb) and binding site was made by choosing "Making binding site for this protein" option. The ligand was then introduced and docking calculation was allowed to run using shapebased search algorithm and AScore scoring function. The scoring function is responsible for evaluating the energy between the ligand and protein target. Flexible docking was allowed by constructing grids over the binding sites of the protein and energy based rotation is set for that ligand group of atoms that do not have rotatable bonds. For each rotation, torsions and created and poses (conformation) are generated during the docking process. For each complex 10 independent runs were conducted and one pose was returned for each run. The best docking model was selected according to the lowest AScore calculated by arguslab and the most suitable binding conformation was selected on the basis of hydrogen bond interaction between the ligand and protein near the substrate binding site. The lowest enegy poses indicate the highest binding affinity as high energy produces the unstable conformations. The resulting receptor model was saved to Brookhaven PDB file from the file the 2D and 3D interactions are viewed in discovery studio 4.1 versions. 


\section{Antimicrobial Assay}

\section{Collection of bacterial strains}

The Clinical isolates of bacterial strains viz., K.pneumonia, B.cerus, S.typhi, E.coli and V. cholerae. The antifungal strains viz., Candida albicans, A.niger, A. Flavus, C. neoformans and F.oxysporum. These strains were obtained from the Department of Botany, Annamalai University, Annamalainagar, Tamil Nadu, India. The strains were inoculated on a sterile medium and subcultured on to Mueller Hinton Agar plates, these strains are maintained on agar slant at $4{ }^{\circ} \mathrm{C}$.

\section{Disc diffusion assay}

Antibacterial and antifungal activity was performed by the disc diffusion method. About $1 \mathrm{mg} / \mathrm{mL}$ stock solution was prepared by dissolving the test compounds (7a-f) in 50\% DMSO. The sterile paper disc with $6 \mathrm{~mm}$ diameter was impregnated with concentration of $200 \mathrm{mg} / \mathrm{mL}$ and the discs were placed in Mueller Hinton Broth for bacteria and Sabourauds dextrose broth for fungi. The plates were incubated at $37{ }^{\circ} \mathrm{C}$ for bacteria and $28{ }^{\circ} \mathrm{C}$ for fungi in incubator. The zone of inhibition for bacteria was visually examined at $37{ }^{\circ} \mathrm{C}$ for $24 \mathrm{~h}$ and fungi was visually examined at $28{ }^{\circ} \mathrm{C}$ for $72-96 \mathrm{~h}$. Streptomycin was used as a standard positive control for bacteria and ketaconazole was used as a standard positive control for fungi under analogues conditions. All the tests were carried out in triplicate.

\section{Minimum Inhibitory Concentration (MIC)}

Dilution susceptibility testing method was used for MIC determination with reference to the cited literature. The test compounds were dissolved in $1 \mathrm{ml}$ of chloroform. The different test concentrations of test compounds were $200-3.125 \mu \mathrm{g} / \mathrm{ml}$. It was then serially diluted in to two folds. Wherein, $100 \mathrm{ml}$ of sterile Mueller Hinton Broth for bacteria and Sabourauds Dextrose broth for fungus was decanted into each well of a sterile 96-well micro plate. Highest concentration of the test compounds added at $100 \mathrm{ml}$ to the first well. After mixing of the above, $100 \mathrm{ml}$ of the same was transferred to the second well and in this way; the dilution procedure was continued as a series of dilution of $200-3.125 \mu \mathrm{g} / \mathrm{ml}$ respectively. Inoculums solution at $5 \mathrm{ml}$ was added to every well. Being incubated for $24 \mathrm{~h}$ at $37^{\circ} \mathrm{C}$ for bacteria and $28^{\circ} \mathrm{C}$ for fungi, the tubes were monitored for turbidity as growth and non-turbidity as no growth. The MIC values were interpreted as the highest dilution (lowest concentration) of the sample, which showed clear fluid with no development of turbidity. Bacterial and fungal growth was indicated by the measure of a white pellet on well bottom.

\section{Results and Discussion}

In the IR spectrum of 3'-benzoyl-5'-(furan-2-yl)-4'-phenylspiro[indoline-3,2'-pyrrolidin]-2one, the -NH group of indolone moiety exhibited a sharp absorption peak at higher frequency at $3256 \mathrm{~cm}^{-1}$ due to the presence of adjacent carbonyl group whereas the peak observed lower frequency at $3110 \mathrm{~cm}^{-1}$ was assigned to - $\mathrm{NH}$ group of pyrrolidine ring. A strong absorption band at $1714 \mathrm{~cm}^{-1}$ was due to indolone carbonyl stretching and a shoulder band at $1700 \mathrm{~cm}^{-1}$ due to benzoyl carbonyl stretching. The aromatic and aliphatic $\mathrm{C}-\mathrm{H}$ stretching absorption bands are observed in the region of 2853-3110 $\mathrm{cm}^{-1}$. The observed imine and aromatic $\mathrm{C}-\mathrm{H}$ stretching frequencies are the evidences for the formation of compounds 4a-g. ${ }^{1} \mathrm{H}$ NMR spectra of compounds $\mathbf{4 a - g}$ have been recorded in the solvent $\mathrm{CDCl}_{3}$. The signals of the ${ }^{1} \mathrm{H}$ NMR spectra were assigned based on their positions, multiplicities and integral values. In ${ }^{1} \mathrm{H}$ NMR spectrum of the representative compound 4a, there was a multiplet in the region of 6.91-7.91 ppm corresponding to 14 protons are assigned to the aromatic protons. A broad doublet appeared at $4.55 \mathrm{ppm}$ is assigned to $\mathrm{H}-5$ proton due to its coupling with H-4 proton. A multiplet appeared at $5.54 \mathrm{ppm}$ is assigned to $\mathrm{H}-3$ and $\mathrm{H}-4$ protons due to its coupling of H-3, H-4 and H-5 protons. A doublet appeared at $6.00 \mathrm{ppm}$ is assigned to H-3" due to its coupling with H-4" proton. A broad singlet appeared at $6.13 \mathrm{ppm}$ is assigned to H-4" proton. A broad doublet appeared at $6.66 \mathrm{ppm}$ is assigned to $\mathrm{H}-5^{\prime \prime}$ proton due to its coupling with 
H-4" proton. From these observations we have confirmed the formation of synthesized compounds 4a-g. ${ }^{13} \mathrm{C}$-NMR spectrum exhibited the occurrence of two carbonyl carbons, one due to benzoyl and another due to indolone moiety at 196.5 and $180.3 \mathrm{ppm}$ respectively and the signals of the aromatic carbons are observed in the region of 142.5-108.2 ppm. The spiro carbon (C-2) of the pyrrolidine ring appeared as the most downfield signal at $72.2 \mathrm{ppm}$ among all the carbons of this ring, while the peak at $57.0 \mathrm{ppm}$ was regarded due to C-3 because of an adjacent carbonyl group of benzoyl moiety. Further a signal observed at $54.5 \mathrm{ppm}$ was assigned to C-4 carbon and another most upfield signal observed at $52.4 \mathrm{ppm}$ was due to C-5 carbon. 3", 4" and 5" carbon signals are observed at 108.2, 109.8 and $110.1 \mathrm{ppm}$ respectively. In the HSQC spectrum, the H-4 proton signal correlates with the analogous carbon signal at $54.5 \mathrm{ppm}$. The H-3 and H-5 proton signal correlates with the analogous carbon signals at 57.0 and $52.4 \mathrm{ppm}$. The H-2 proton signal correlates with consequent carbon signal at $72.2 \mathrm{ppm}$. The $3^{\prime \prime}, 4^{\prime \prime}$ and $5^{\prime \prime}$ proton signals correlates with the corresponding carbon signals at $108.24,109.85$ and $110.15 \mathrm{ppm}$. All the aromatic proton signals are correlated with the corresponding carbon signals. The ${ }^{1} \mathrm{H}-{ }^{13} \mathrm{C}$ cosy correlations further confirmed the one dimensional ${ }^{1} \mathrm{H}$ NMR spectral assignments.

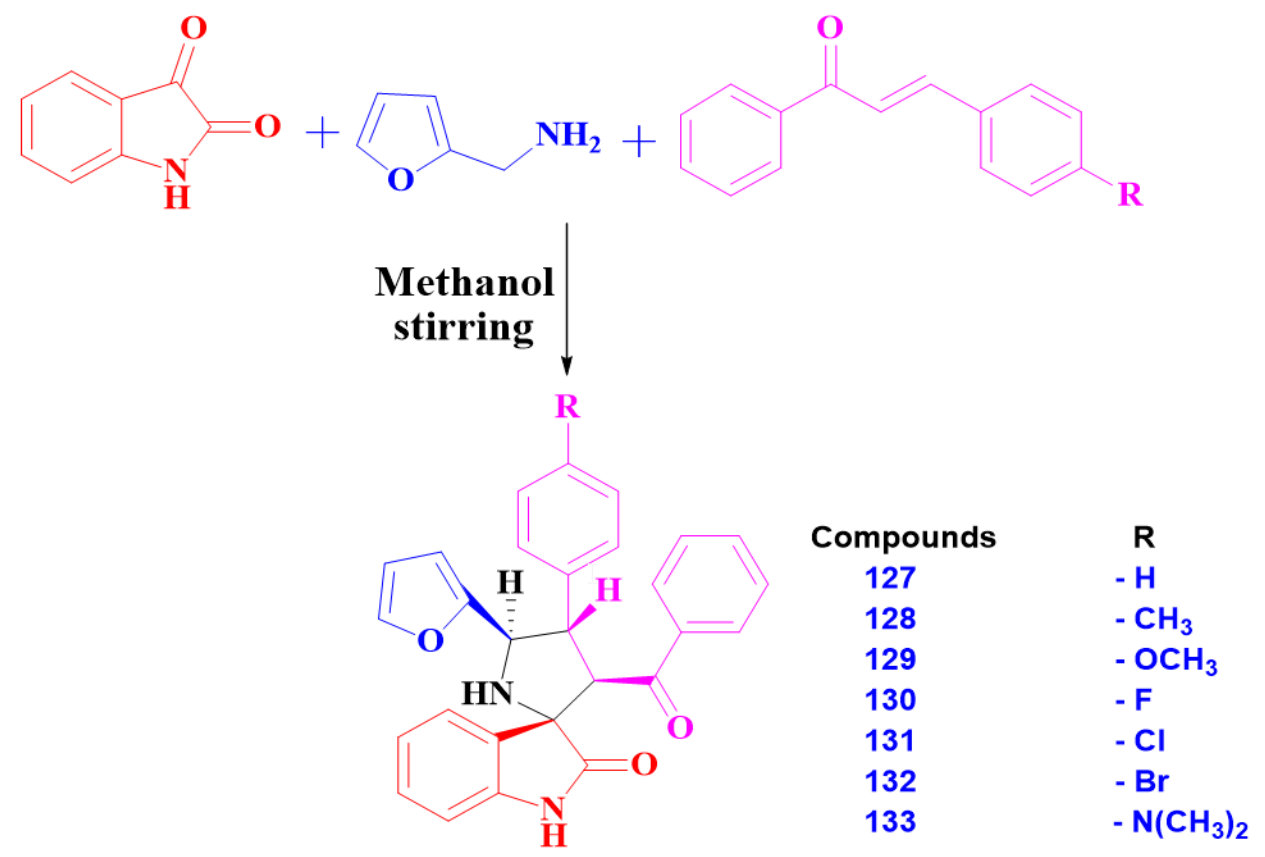

Inhibitory Activity towards glucosamine-6-phosphate synthase (PDB ID: 2VF5)

Molecular docking studies were implementing to investigate the precise binding site of ligand on protein. The synthesized six analogues docked with antibacterial protein glucosamine-6phosphate synthase. The Analogues 4a-g showed best ligand pose energy ranging from -11.06 to $13.45 \mathrm{kcal} / \mathrm{mol}$ in $2 \mathrm{VF}$. The $3 \mathrm{D}$ and $2 \mathrm{D}$ view of compound $4 \mathrm{a}$ with the standard drug (glucosamine-6-phospahte synthase) are shown in Fig. 1. The Best ligands pose energy, Van der Waals interaction, conventional hydrogen bond, pi-pi interaction, alkyl and pi-alkyl interaction of all the docked compounds including standard drug were presented in Table $\mathbf{1}$. The compound 4a showed very highest ligand pose energy $-13.45 \mathrm{kcal} / \mathrm{mol}$ compared to glucosamine-6-phosphate $(-6.31 \mathrm{kcal} / \mathrm{mol})$. The analogue 4a is surrounded by Van der Waals, Alkyl, pi-alkyl and pi-loan pair interactions. ALA327, GLY301, LYS487, THR302 and GLU481 residues surrounded by Van der Waals interactions. The amino acid ASN305 interface in furfuryl ring exhibited Pi-Loan pair interaction with the bond distance of $4.42 \AA$. CYS300, ILE326 and TYR304 amino acids accompanying benzoyl phenyl ring with alkyl and Pi- alkyl interactions. The amino acids LEU484 and LEU480 interact in furfuryl ring in alkyl and Pi-alkyl interactions. This ensured the binding affinity and results in an increased 2VF5 inhibitory activity. 
But the standard drug molecules surrounded with Van der Waals, conventional hydrogen bond, carbon hydrogen bond with less amino acid interaction and also the bond distance is very high compared to analogue $\mathbf{4 a}$. The compounds $\mathbf{4 d}, \mathbf{4 e}$ and $\mathbf{4 f}$ containing halogen atoms also showed high ligand pose energy.
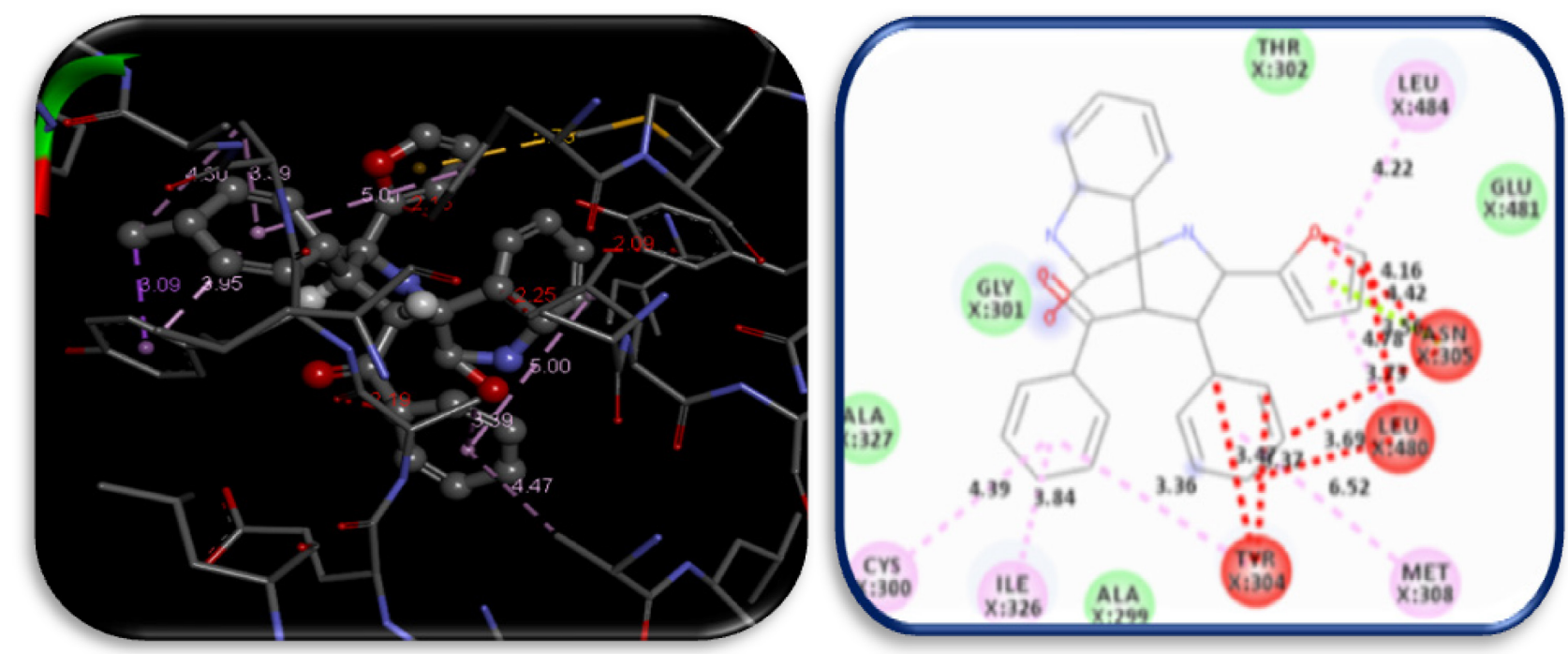

Figure 1(a). 3D and 2D view of binding interactions of compound

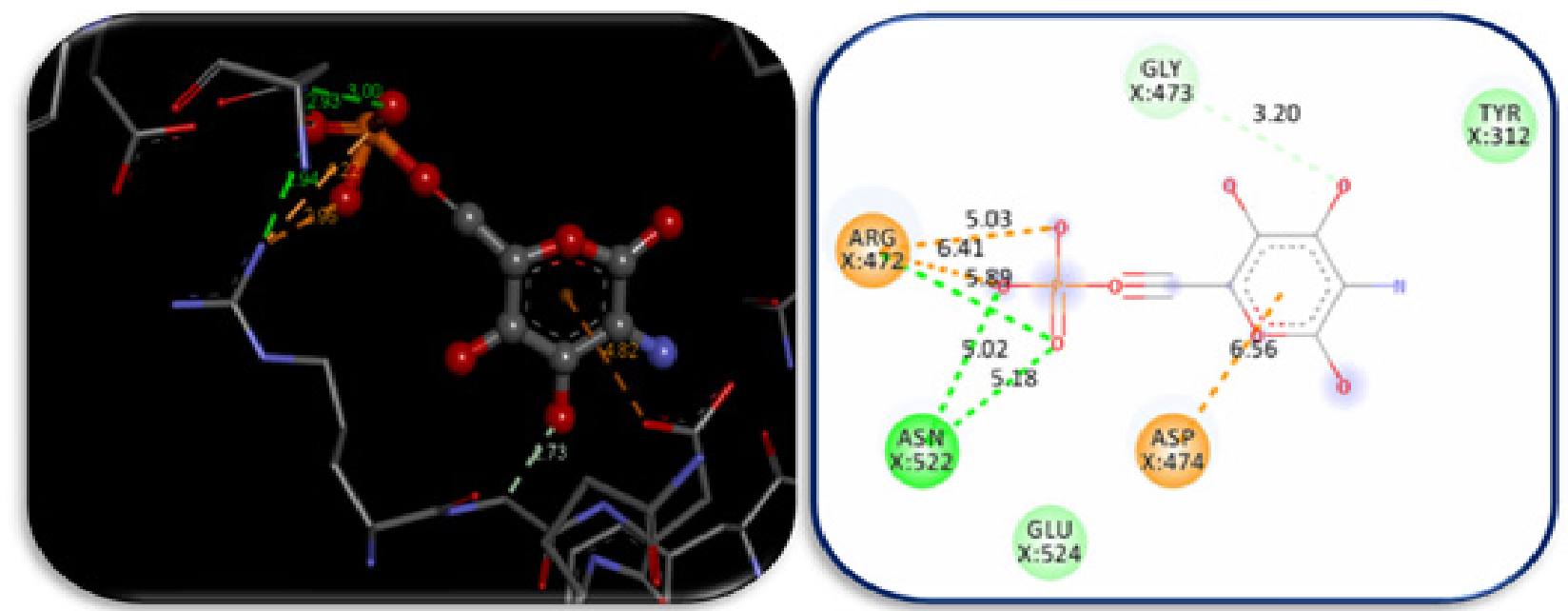

Figure 1(b). 3D and 2D view of binding interactions of standard drug 2VF5

Inhibitory activity towards human lanosterol 14-alpha dimethylase in complex with ketaconazole (PDB ID: 3LD6)

A docked 2D image of compound $\mathbf{4 b}$ with the standard molecule is shown in Fig. 2. The Best ligand pose energy, Van der Waals interaction, conventional hydrogen bond, pi-pi interaction, alkyl and pi-alkyl interaction of all the docked compounds including standard drug were presented in Table 2. The best ligand pose energy of compound $\mathbf{4 b}$ is $-18.06 \mathrm{kcal} / \mathrm{mol}$ while the standard drug molecule is $-10.47 \mathrm{kcal} / \mathrm{mol}$. In the binding mode, the compound $\mathbf{4 b}$ was attractively bound to 3LD6 via Van der Waals interaction, pi-sigma, pi-lone pair, alkyl and pi-alkyl interactions. Compound 4b surrounded by Van der Waals interaction with the amino acid residues HIS489, ILE379, MET381, MET378, MET487, HIS236 and GLY78. One pi-sigma interaction with PHE105 residues in methyl substituted phenyl ring. The TRP758 amino acid interacts in alkyl interaction with indolone phenyl ring. TRP239 residues interface with one pilone pair interaction in benzoyl carbonyl atom. Totally eight residues interact with alkyl and pi-alkyl interaction with the analogue 4b. Three residues like LYS103, VAL101 and LEU240 accompanying benzoylphenyl ring with 
different bond distances. The remaining residues MET100, CYS402, PHE98 and TYR107 act together in methyl group and methyl substituted phenyl ring in different bond distances. The standard drug molecule is surrounded only less interactions like Van der Waals, carbon hydrogen bond, one pi-sigma, one pi-pi T shaped and alkyl and pi-alkyl interaction with fewer residues and also the bond distance is very high. This is confirmed the binding affinity and results in an increased 3LD6 inhibitory activity compared to standard drug molecule.

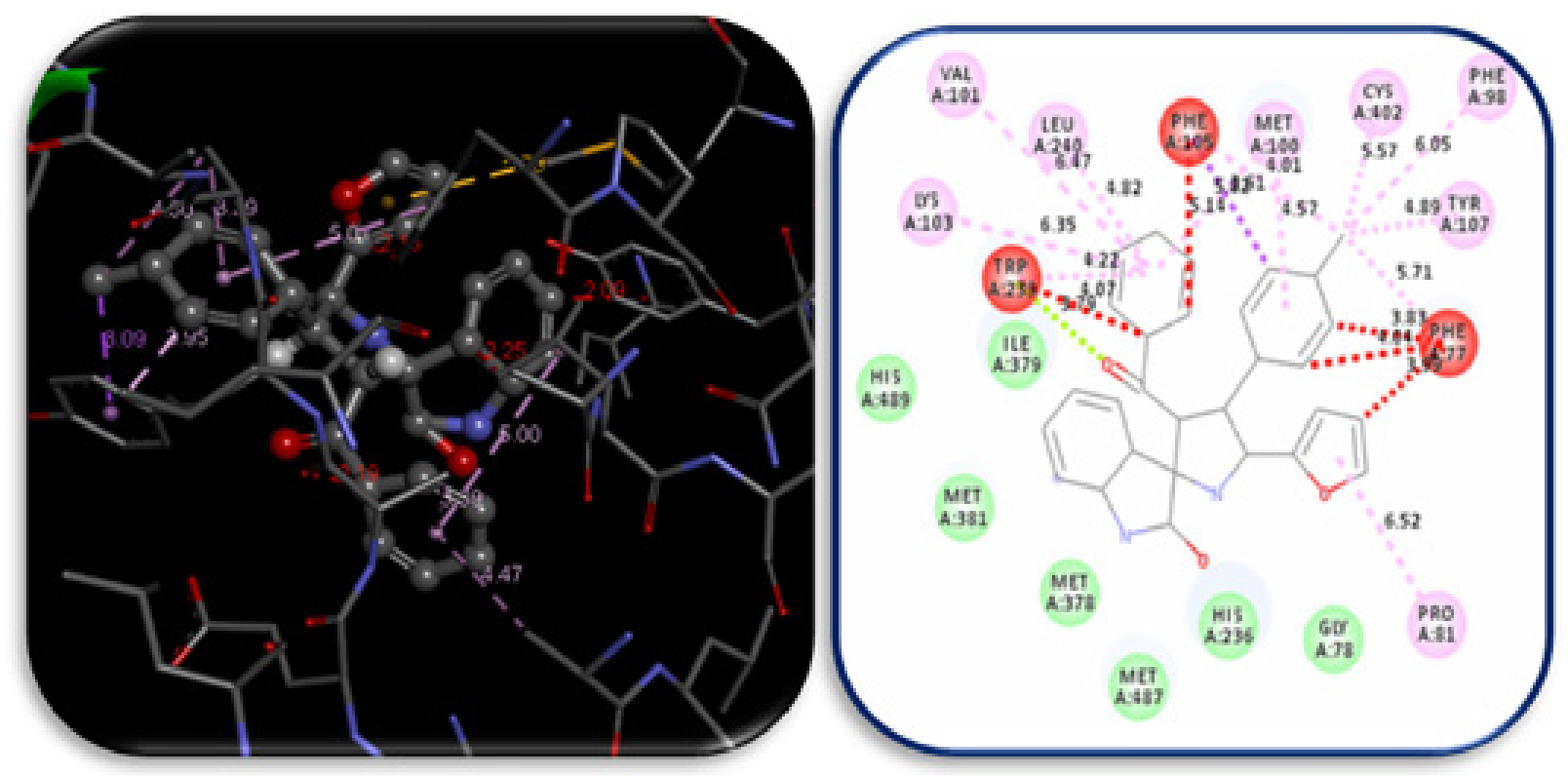

Figure 2(a). 3D and 2D view of binding interactions of compound

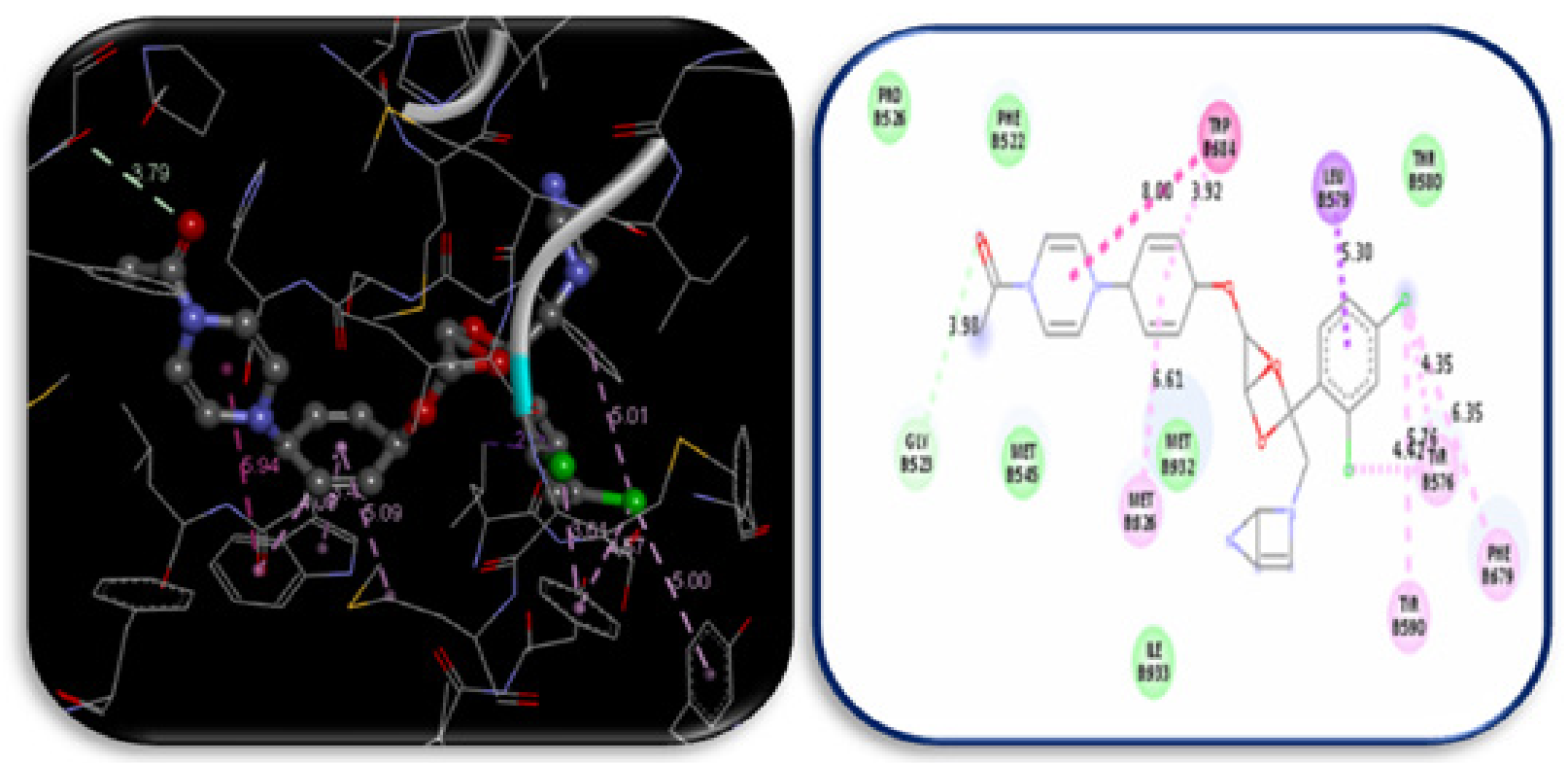

Figure 2(b). 3D and 2D view of binding interactions of standard drug 3LD6 
Table 1. Different types of interactions in the compounds $4 \mathbf{a}-\mathbf{4 g}$ with $\mathbf{2 V F 5}$

\begin{tabular}{|c|c|c|c|c|}
\hline Compds. & $\begin{array}{l}\text { Best ligand } \\
\text { pose energy }\end{array}$ & $\begin{array}{c}\text { Van der Waals } \\
\text { interactions }\end{array}$ & $\begin{array}{c}\text { Alkyl and Pi-alkyl } \\
\text { interaction }\end{array}$ & Others \\
\hline $4 \mathbf{a}$ & -13.45 & $\begin{array}{l}\text { ALA327, LY301, } \\
\text { LYS487, HR302, } \\
\text { GLU481 }\end{array}$ & $\begin{array}{c}\text { CYS300, ILE326, } \\
\text { MET308, LEU480, } \\
\text { LEU484 }\end{array}$ & ASN305(Pi-loan pair) \\
\hline $4 b$ & -11.77 & $\begin{array}{c}\text { GLU501,GLU495, } \\
\text { LYS487 }\end{array}$ & $\begin{array}{c}\text { ALA498, TYR497, } \\
\text { TYR476, ALA496, } \\
\text { ALA483 }\end{array}$ & $\begin{array}{l}\text { TYR } 497 \text { (Pi -sigma), } \\
\text { MET308 (Pi-sulfur) }\end{array}$ \\
\hline $4 c$ & -11.06 & $\begin{array}{c}\text { ASN305, TYR304, } \\
\text { ALA498, GLU495, } \\
\text { ALA494 }\end{array}$ & $\begin{array}{l}\text { ALA483, LEU484, } \\
\text { MET308, TYR476, } \\
\text { LEU480, ALA496 }\end{array}$ & $\begin{array}{l}\text { LYS487, ALA496 (Conventional } \\
\text { hydrogen bond) LEU484 (Pi - } \\
\text { sigma) } \\
\text { GLU495 (carbon hydrogen bond) }\end{array}$ \\
\hline $4 d$ & -11.54 & $\begin{array}{l}\text { LEU484, THR302, } \\
\text { GLU325, GLU329, } \\
\text { MET308 }\end{array}$ & - & $\begin{array}{l}\text { LEU480 (Pi-sigma), } \\
\text { GLY301(Halogen fluorine }\end{array}$ \\
\hline $4 e$ & -11.65 & $\begin{array}{l}\text { LYS487, GLU495, } \\
\text { GLU501 }\end{array}$ & $\begin{array}{l}\text { ALA483, ALA496, } \\
\text { LEU480, TYR497, } \\
\text { ALA498, TYR476 }\end{array}$ & $\begin{array}{l}\text { MET308 } \\
\text { (Pi-sulfur) }\end{array}$ \\
\hline $4 f$ & -12.03 & $\begin{array}{l}\text { GLU495, TYR497, } \\
\text { ALA498, GLY301, } \\
\text { ASN305, LEU484 }\end{array}$ & $\begin{array}{c}\text { ALA496, TYR304, } \\
\text { TYR476, }\end{array}$ & $\begin{array}{c}\text { ILE326 (Pi-sigma) } \\
\text { LYS487, (Conventional } \\
\text { hydrogen bond) }\end{array}$ \\
\hline $4 \mathrm{~g}$ & -10.95 & $\begin{array}{l}\text { ALA327, ALA299, } \\
\text { MET308, GLU481 }\end{array}$ & $\begin{array}{l}\text { ALA483, ALA496, } \\
\text { LEU484, LYS487, } \\
\text { LEU480 }\end{array}$ & $\begin{array}{l}\text { GLY301, TYR476, ASN305 } \\
\text { (Carbon and Pi-Donor hydrogen } \\
\text { bond), ILE326 (Pi-sigma), } \\
\text { CYS300 (Pi-sulfur) }\end{array}$ \\
\hline $\begin{array}{l}\text { Standard } \\
\text { Drug }\end{array}$ & -6.31 & GLU524, TYR312 & - & $\begin{array}{l}\text { ASN522, ARG472 (Conventional } \\
\text { hydrogen), ASP474, } \\
\text { ARG472(salt bridge, attractive } \\
\text { charge, pi-anion) GLY473 } \\
\text { (carbon hydrogen bond) }\end{array}$ \\
\hline
\end{tabular}

Table 2. Different types of interaction in compounds 4a-g with 3LD6

\begin{tabular}{|c|c|c|c|c|}
\hline Compds. & $\begin{array}{l}\text { Best ligand } \\
\text { pose energy }\end{array}$ & $\begin{array}{c}\text { Van der Waals } \\
\text { interactions } \\
\end{array}$ & $\begin{array}{c}\begin{array}{c}\text { Alkyl and Pi-alkyl } \\
\text { interaction }\end{array} \\
\end{array}$ & Other interaction \\
\hline $4 a$ & -16.62 & $\begin{array}{l}\text { LYS103, VAL101, PHE98, } \\
\text { TRY131, LEU134 }\end{array}$ & $\begin{array}{l}\text { LEU240, MET487, MET381, } \\
\text { TRP239, CYS402, ILE379, } \\
\text { TYR107 }\end{array}$ & $\begin{array}{l}\text { MET100 (sulfur-x), } \\
\text { PHE105 (Pi-sigma), } \\
\text { PHE77, HIS236 (Pi-Donor } \\
\text { hydrogen bond) }\end{array}$ \\
\hline $4 \mathrm{~b}$ & -18.06 & $\begin{array}{l}\text { HIS489, ILE379, MET381, } \\
\text { MET378, MET487, HIS236, } \\
\text { GLY78 }\end{array}$ & $\begin{array}{l}\text { LYS103, VAL101, LEU240, } \\
\text { TRP239, MET100, TYR107 } \\
\text { CYS402, PHE98, HE77. }\end{array}$ & $\begin{array}{l}\text { PHE105 (Pi-sigma), } \\
\text { TRP239 (Pi-lone pair) }\end{array}$ \\
\hline $4 c$ & -14.50 & $\begin{array}{l}\text { MET100, LEU240, } \\
\text { LYS103, VAL101, } \\
\text { VAL130, TYR131, } \\
\text { PHE234, HIS489, MET378, }\end{array}$ & $\begin{array}{l}\text { LEU134, ILE379, TYR107, } \\
\text { LYS402, PHE77, PHE105, } \\
\text { TRP239 }\end{array}$ & - \\
\hline $4 d$ & -13.81 & $\begin{array}{l}\text { MET381, ILE377, MET378, } \\
\text { HIS489, ILE488, TYR145 }\end{array}$ & $\begin{array}{l}\text { ILE379, MET487, PHE234, } \\
\text { LEU134 }\end{array}$ & $\begin{array}{l}\text { VAL130 (Conventional } \\
\text { hydrogen bond), PHE234 } \\
\text { (Pi-loan pair), TYR131 }\end{array}$ \\
\hline $4 e$ & -14.26 & $\begin{array}{l}\text { VAL130, MET378, HIS489, } \\
\text { ILE377, ILE488, PHE139, } \\
\text { TYR145 }\end{array}$ & $\begin{array}{l}\text { ILE379, MET487, PHE234, } \\
\text { LEU134, MET381, TRP239, } \\
\text { TYR131 }\end{array}$ & $\begin{array}{l}\text { PHE234 (Pi-sigma), TYR } \\
\text { 131(Carbon hydrogen } \\
\text { bond) }\end{array}$ \\
\hline $4 f$ & -14.29 & $\begin{array}{l}\text { MET378, HIS489, HIS236, } \\
\text { ILE488, PHE139, TYR145, } \\
\text { MET381, ILE377 }\end{array}$ & $\begin{array}{l}\text { ILE379, MET487, PHE234, } \\
\text { LEU134, TYR131 }\end{array}$ & $\begin{array}{l}\text { VAL130 (Conventional } \\
\text { Hydrogen bond), TYR131 }\end{array}$ \\
\hline $4 \mathrm{~g}$ & -13.57 & $\begin{array}{l}\text { MET378, HIS489, HIS236, } \\
\text { ILE488, PHE139 }\end{array}$ & $\begin{array}{l}\text { LEU579, TRP684,TRY590, } \\
\text { MET826, MET932, TYR59. }\end{array}$ & - \\
\hline $\begin{array}{l}\text { Standard } \\
\text { Drug }\end{array}$ & -10.47 & $\begin{array}{l}\text { PRO526, PHE522, } \\
\text { MET545, MET932, } \\
\text { THR580, ILE,933 } \\
\end{array}$ & $\begin{array}{l}\text { MET826, TYR590, PHE679, } \\
\text { TYR576 }\end{array}$ & $\begin{array}{l}\text { GLY523 (Carbon hydrogen } \\
\text { bond), LEU579 (Pi-sigma) }\end{array}$ \\
\hline
\end{tabular}




\section{Antimicrobial Studies}

\section{In vitro antibacterial activity}

The synthesized compounds were screened for their antimicrobial activity against $K$. pneumoniae, B. cereus, S. typhi, E. coli and $V$. cholarae with the standard ciprofloxacin using an agar-well diffusion method for the determination of MIC (minimum inhibitory concentration of the compound). The compounds to be tested were dissolved in DMSO and different dilutions of the samples were prepared. A similar procedure was used for the commercial antibiotics streptomycin, which were used as positive controls for bacteria. The test organisms were transferred into freshly prepared Mueller-Hinton agar plates and evenly spread. After letting the plates dry for 5 minutes, wells were bored into the agar. $0.1 \mathrm{~mL}$ of each test compound and streptomycin (positive control) were added into the well, and then the plates were incubated at $37^{\circ} \mathrm{C}$ for 24 hours (for bacteria) and the zone of inhibition were measured. Compounds which showed a zone of inhibition less than $1.8 \mathrm{~cm}^{-1}$ were taken as a resistant, those with $1.8-2.0 \mathrm{~cm}^{-1}$ were taken as intermediate and those with zone of more than $2 \mathrm{~cm}^{-1}$ were assumed to be sensitive. Suitable dilutions of test compounds were added to $10 \mathrm{~mL}$ broth tubes inoculated with the test culture and incubated for 24 hours, such that their MIC activity was studied at 12, 15, 18 and $20 \mathrm{mg} \mathrm{mL}^{-1}$. The tubes were checked for turbidity by comparing the positive control and negative control of the compounds against different strains of microorganism. It is confirmed from the in-vitro antimicrobial activity data of compounds $4 \mathbf{a}, \mathbf{4 b}$ and $\mathbf{4 g}$ display the highest activity MIC $12.5 \mathrm{mg} \mathrm{mL}^{-1}$ against Klepsilae pneumonia while 4c, 4d, $\mathbf{4 e}$ and $\mathbf{4 f}$ respectively, showed somewhat inferior activity compared to the standard streptomycin (MIC $12.5 \mathrm{mg} \mathrm{mL}^{-1}$ ). In the case of B. Cereus, compounds $\mathbf{4 a}, \mathbf{4 b}, \mathbf{4 c}$ and $\mathbf{4 f}$ were found to be the most active derivative in vitro with a MIC of $12.5,25,25$ and $12.5 \mathrm{mg} \mathrm{mL}^{-1}$, respectively. Compounds $4 \mathbf{a}$ and $\mathbf{4 b}$ showed strong activity with MIC $12.5, \mathrm{mg} \mathrm{mL}^{-1}$ against S.typhi. However, the compounds $\mathbf{4 c}, \mathbf{4 d}, \mathbf{4 e}$ and $\mathbf{4 f}$ showed good to moderate activity whereas compound $\mathbf{4 g}$ did not show the activity in the concentration range tested. In the case of E. coli, compound $4 \mathbf{e}$ showed good to moderate activity with MIC $25 \mathrm{mg} \mathrm{mL}^{-1}$. Further compounds $\mathbf{4 a}$, $4 \mathbf{e}$ and $\mathbf{4 f}$ showed good activity against $V$. cholerae whereas the compounds $\mathbf{4 b}, \mathbf{4 c}, \mathbf{4 d}$ and $4 \mathbf{e}$ showed moderate activity as compared to the standard antimicrobial agent streptomycin (MIC $12.5 \mathrm{mg} \mathrm{mL}^{-1}$ ). The compounds $\mathbf{4 e}$ and $\mathbf{4 f}$ showed good activity against almost the majority of the bacterial strains, whereas $\mathbf{4 b}, \mathbf{4 c}$ and $\mathbf{4 g}$ showed weak activity against the majority of the bacterial strains. The tendency of the

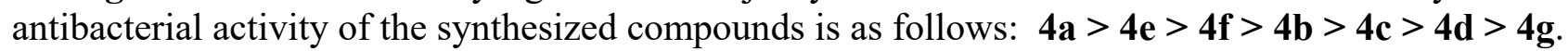
Minimum inhibitory concentration of antibacterial activities is shown in Table 3. The Bar diagram of MIC values of antibacterial activities are shown in Fig. 3.

\section{In vitro antifungal activity}

3-benzoyl-5-(furan-2-yl)-4-phenylspiro[indoline-3,2-pyrrolidin]-2-one derivatives 4a-g were also screened for their in-vitro antifungal activity with fungal strains viz., C. albicans, A. niger, A. flavus, $C$. neoformans and F. oxysporum. Here, Ketoconazole be used as the standard drug. MIC character ranging from $6.25-12.5 \mathrm{mg} / \mathrm{mL}$ is listed in Table 4. Compound $\mathbf{4 b}(\mathrm{MIC}=3.125 \mathrm{lg} / \mathrm{mL})$ methyl substituent in the para position of phenyl ring in C-4 carbon at five membered pyrrole heterocyclic ring showed superior antifungal activity against $C$. albicans and A. niger. Compound $\mathbf{4 b}(\mathrm{MIC}=3.125 \mathrm{mg} / \mathrm{mL})$ left out any substituent in the para position of phenyl ring in $\mathrm{C}-4$ carbon at pyrrole five membered heterocyclic ring exhibited excellent antifungal action than the standard drug against $C$. albicans. Compound $\mathbf{4 c}$, showed equivalent activity against $C$. albicans, A. niger and $A$. flavus fungal strains. The compounds $\mathbf{4 d}, \mathbf{4 e}$ and $\mathbf{4 f}$ showed excellent activity against almost all the fungal strains except $C$. neoformans and F.oxysporum. Originally, the tendency of the antifungal activity of all the compounds is as follows: $\mathbf{4 b}>\mathbf{4 a}>\mathbf{4 c}>\mathbf{4 d}>\mathbf{4 e}>\mathbf{4 f}>\mathbf{4 g}$. The Bar diagram of MIC values of antifungal activities are shown in Fig. 4. 


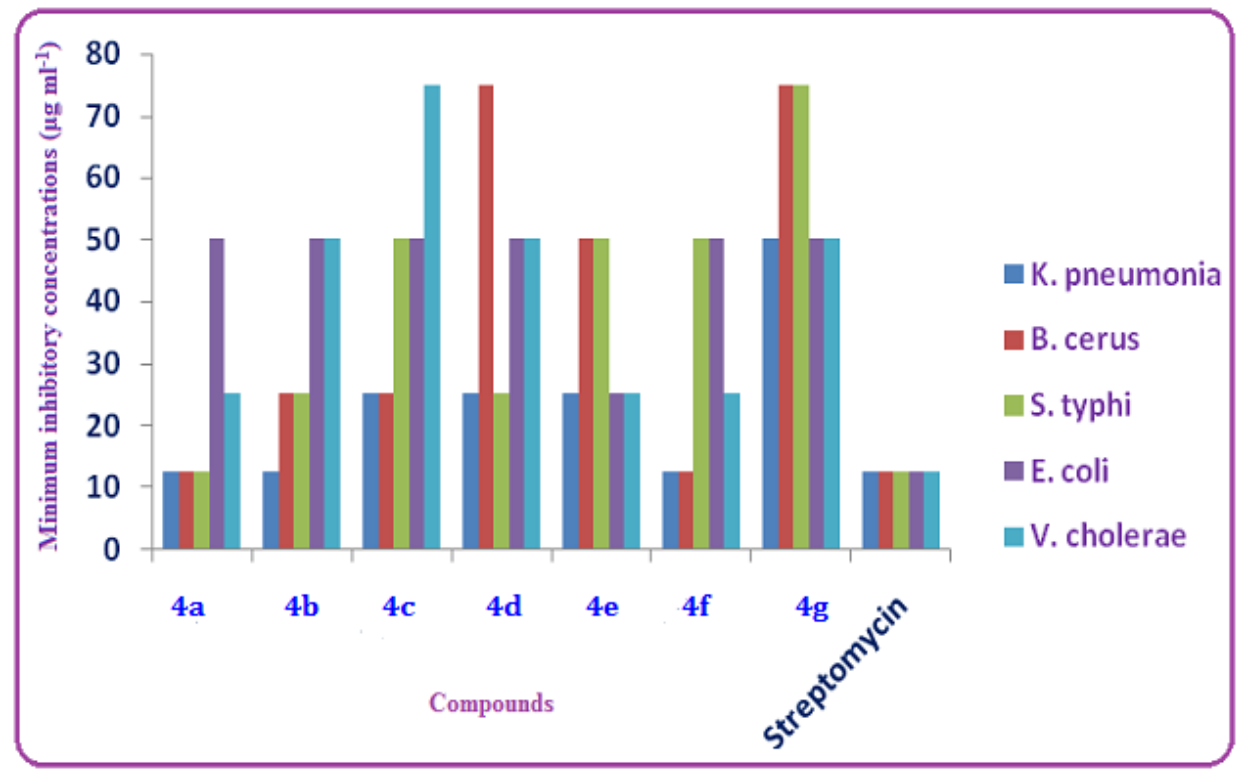

Figure 3. Minimum inhibitory concentrations of antibacterial activity of compounds $4 \mathrm{a}-4 \mathrm{~g}$.

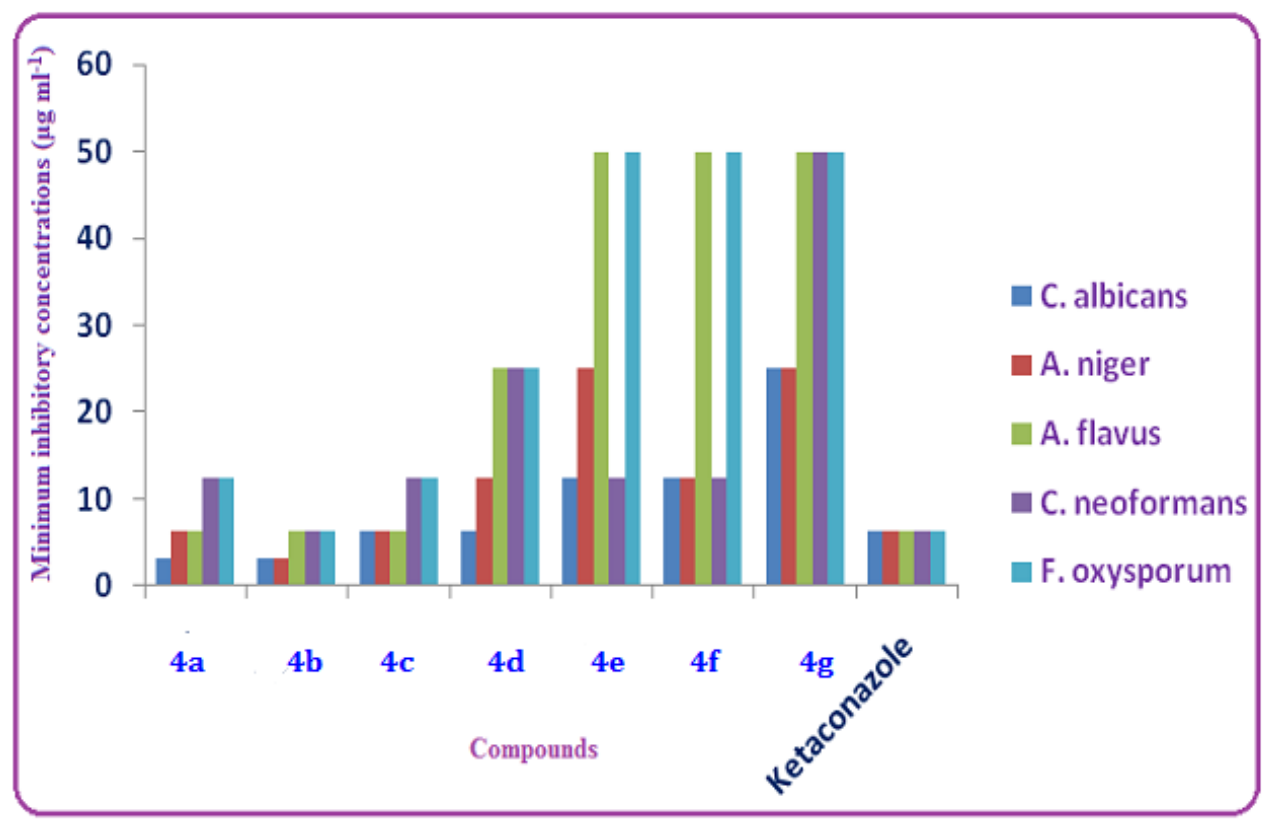

Figure 4. Minimum inhibitory concentrations of antifungal activity of compounds $4 \mathrm{a}-4 \mathrm{~g}$

Table 3. Minimum inhibitory concentration $\left(\mu \mathrm{g} \mathrm{ml}^{-1}\right)$ of antibacterial activity of compounds $\mathbf{4 a - g}$

\begin{tabular}{|c|c|c|c|c|c|}
\hline \multirow{2}{*}{ Compds. } & \multicolumn{5}{|c|}{ Minimum inhibitory concentration $\left(\boldsymbol{\mu g} \mathbf{~ m}^{-1}\right)$} \\
\cline { 2 - 6 } & $\begin{array}{c}\boldsymbol{K} . \\
\text { pneumonia }\end{array}$ & $\begin{array}{c}\boldsymbol{B} . \\
\text { cerus }\end{array}$ & $\begin{array}{c}\boldsymbol{S} . \\
\text { typhi }\end{array}$ & $\begin{array}{c}\boldsymbol{E} \text {. } \\
\text { coli }\end{array}$ & $\begin{array}{c}\boldsymbol{V} \text {. } \\
\text { cholerae }\end{array}$ \\
\hline \hline $\mathbf{4 a}$ & 12.5 & 12.5 & 12.5 & 50 & 25 \\
\hline $\mathbf{4 b}$ & 12.5 & 25 & 25 & 50 & 50 \\
\hline $\mathbf{4 c}$ & 25 & 25 & 50 & 50 & 75 \\
\hline $\mathbf{4 d}$ & 25 & 75 & 25 & 50 & 50 \\
\hline $\mathbf{4 e}$ & 25 & 50 & 50 & 25 & 25 \\
\hline $\mathbf{4 f}$ & 12.5 & 12.5 & 50 & 50 & 25 \\
\hline $\mathbf{4 g}$ & 50 & 75 & 75 & 50 & 50 \\
\hline Streptomycin & 12.5 & 12.5 & 12.5 & 12.5 & 12.5 \\
\hline
\end{tabular}


Table 4. Minimum inhibitory concentration $\left(\mu \mathrm{g} \mathrm{ml}^{-1}\right)$ of antifungal activity of compounds $\mathbf{4 a - g}$

\begin{tabular}{|c|c|c|c|c|c||}
\hline \multirow{3}{*}{ Compds. } & \multicolumn{5}{|c|}{ Minimum inhibitory concentration $\left(\boldsymbol{\mu g} \mathbf{~ m}^{-1}\right)$} \\
\cline { 2 - 6 } & $\begin{array}{c}\boldsymbol{C} \text {. } \\
\text { albicans }\end{array}$ & $\begin{array}{c}\boldsymbol{A} . \\
\text { niger }\end{array}$ & $\begin{array}{c}\boldsymbol{A} . \\
\text { flavus }\end{array}$ & $\begin{array}{c}\boldsymbol{C} . \\
\text { neoformans }\end{array}$ & $\begin{array}{c}\boldsymbol{F} . \\
\text { oxysporum }\end{array}$ \\
\hline \hline $\mathbf{4 a}$ & 3.125 & 6.25 & 6.25 & 12.5 & 12.5 \\
\hline $\mathbf{4 b}$ & 3.125 & 3.125 & 6.25 & 6.25 & 6.25 \\
\hline $\mathbf{4 c}$ & 6.25 & 6.25 & 6.25 & 12.5 & 12.5 \\
\hline $\mathbf{4 d}$ & 6.25 & 12.5 & 25 & 25 & 25 \\
\hline $\mathbf{4 e}$ & 12.5 & 25 & 50 & 12.5 & 50 \\
\hline $\mathbf{4 f}$ & 12.5 & 12.5 & 50 & 12.5 & 50 \\
\hline $\mathbf{4 g}$ & 25 & 25 & 50 & 50 & 50 \\
\hline Ketaconazole & 6.25 & 6.25 & 6.25 & 6.25 & 6.25 \\
\hline
\end{tabular}

\section{3'-benzoyl-5'-(furan-2-yl)-4'-phenylspiro[indoline-3,2'-pyrrolidin]-2-one (4a)}

M.F.: $\mathrm{C}_{28} \mathrm{H}_{22} \mathrm{~N}_{2} \mathrm{O}_{3}$, m.p. $\left({ }^{0} \mathrm{C}\right)$ : 248-251, Yield(\%): 84, IR (Neat, $\left.\mathrm{cm}^{-1}\right) ; 1714.80,1700.62(\mathrm{C}=\mathrm{O})$, 3250.50, 3110. $84(\mathrm{NH}) .{ }^{1} \mathrm{H}$ NMR $\left(\mathrm{CDCl}_{3}, \mathrm{ppm}\right) ; \delta: 4.55(\mathrm{~d}, \mathrm{H}-5, \mathrm{~J}=8.4 \mathrm{~Hz}), 5.54(\mathrm{~s}, \mathrm{H}-3, \mathrm{H}-4)$, $6.00 \quad\left(\mathrm{~s}, 1 \mathrm{H}, 3^{\prime \prime}\right.$ furan), $6.12\left(\mathrm{~s}, 1 \mathrm{H}, 4^{\prime \prime}\right.$ furan), $6.67\left(\mathrm{~d}, 1 \mathrm{H}, \mathrm{J}=6.4 \mathrm{~Hz}, 5^{\prime \prime}\right.$ furan), 6.91-7.91 (m, 14H Aromatic protons). ${ }^{13} \mathrm{C}$ NMR $\left(\mathrm{CDCl}_{3}, \mathrm{ppm}\right) ; \delta: 196.5(\mathrm{C}=\mathrm{O}), 180.3(\mathrm{C}=\mathrm{O}), 153.7$ (C-O, furan), 72.2 (C-2), 57.0 (C-3), 54.5 (C-5), 52.4 (C-4), 108.2 (3" carbon), 109.8 (4" carbon), 110.3 (5" carbon), $123.3,123.9,127.7,128.3,128.4,128.5,128.8,129.2$, 129.4, 129.5, 130.0, 133.2, 133.4, 137.1, 140.7, 142.4, 142.5 (Aromatic carbon).

\section{3'-benzoyl-5'-(furan-2-yl)-4'-(p-tolyl)spiro[indoline-3,2'-pyrrolidin]-2-one (4b)}

M.F.: $\mathrm{C}_{29} \mathrm{H}_{24} \mathrm{~N}_{2} \mathrm{O}_{3}$, m.p. $\left({ }^{0} \mathrm{C}\right)$ : 238-242, Yield(\%): 76, IR (Neat, $\left.\mathrm{cm}^{-1}\right) ; 1710.23,1708.42(\mathrm{C}=\mathrm{O})$, 3248.00, 3112. $04(\mathrm{NH}) .{ }^{1} \mathrm{H}$ NMR $\left(\mathrm{CDCl}_{3}, \mathrm{ppm}\right) ; \delta: 2.17\left(\mathrm{~s}, \mathrm{CH}_{3}\right), 4.62(\mathrm{~d}, \mathrm{H}-5, \mathrm{~J}=13.2 \mathrm{~Hz}), 5.56$ (s, H-3, H-4), 6.03 (d, J=3.2 Hz, 1H, 3" furan), 6.13 (s, 1H, 4" furan), 6.86 (d, 1H, J=6.4Hz, 5', furan), 6.87-7.92 (m, 14H Aromatic protons). ${ }^{13} \mathrm{C} \mathrm{NMR}\left(\mathrm{CDCl}_{3}, \mathrm{ppm}\right) ; \delta: 207.1(\mathrm{C}=\mathrm{O}), 190.0(\mathrm{C}=\mathrm{O})$, 158.9 (C-O, furan), 64.2 (C-2), 61.1 (C-3), 54.9 (C-5), 52.3 (C-4), $21.0\left(\mathrm{CH}_{3}\right), 108.1$ (3" carbon), 109.6 (4" carbon), 110.1 (5" carbon), 123.3, 123.9, 127.6, 127.7, 127.8, 127.9, 128.1, 128.2, 128.3, 128.4, $128.5,128.8,129.4,142.4$ (Aromatic carbon).

\section{3'-benzoyl-5'-(furan-2-yl)-4'-(4-methoxyphenyl)spiro[indoline-3,2'-pyrrolidin]-2-one (4c)}

M.F.: $\mathrm{C}_{29} \mathrm{H}_{24} \mathrm{~N}_{2} \mathrm{O}_{4}$, m.p. $\left({ }^{0} \mathrm{C}\right)$ : 236-239, Yield (\%): 78. IR (Neat, $\left.\mathrm{cm}^{-1}\right) ; 1709.67,1710.19(\mathrm{C}=\mathrm{O})$, 3248.05, 3116. $03(\mathrm{NH}) .{ }^{1} \mathrm{H}$ NMR $\left(\mathrm{CDCl}_{3}, \mathrm{ppm}\right) ; \delta: 3.87\left(\mathrm{~s}, \mathrm{OCH}_{3}\right), 4.62(\mathrm{~d}, \mathrm{H}-5, \mathrm{~J}=13.2 \mathrm{~Hz}), 5.56(\mathrm{~d}$, $\mathrm{J}=8.4 \mathrm{~Hz}, \mathrm{H}-3, \mathrm{H}-4), 6.03$ (d, J=2.8Hz, 1H, 3" furan), 6.13 (d, J=5.2Hz, 1H, 4" furan), 6.86 (d, 1H, J= $8.8 \mathrm{~Hz}, 5^{\prime \prime}$ furan), 6.87-7.92 (m, 14H Aromatic protons). ${ }^{13} \mathrm{C} \mathrm{NMR}\left(\mathrm{CDCl}_{3}, \mathrm{ppm}\right) ; \delta: 196.8(\mathrm{C}=\mathrm{O})$, $180.9(\mathrm{C}=\mathrm{O}), 158.7\left(\mathrm{C}-\mathrm{O}\right.$, furan), $72.4(\mathrm{C}-2), 62.3(\mathrm{C}-3), 57.0(\mathrm{C}-5), 52.4(\mathrm{C}-4), 55.0\left(\mathrm{OCH}_{3}\right)$, 107.9 (3" carbon), 109.7 (4" carbon), 110.1(5" carbon), 113.3, 113.5, 114.1, 114.5, 119.8, 122.5, $123.1,123.9,124.5,125.8,126.7,128.3,128.5,128.8,130.3,133.0,137.3,140.1,140.9,142.3$ (Aromatic carbon).

\section{3'-benzoyl-4'-(4-fluorophenyl)-5'-(furan-2-yl)spiro[indoline-3,2'- pyrrolidin]-2-one (4d)}

M.F.: $\mathrm{C}_{28} \mathrm{H}_{21} \mathrm{FN}_{2} \mathrm{O}_{3}$, m.p. $\left({ }^{0} \mathrm{C}\right)$ : 226-230, Yield(\%): 80, IR (Neat, $\left.\mathrm{cm}^{-1}\right) ; 1713.00,1718.61(\mathrm{C}=\mathrm{O})$, 3242.51, $3110.02(\mathrm{NH}) .{ }^{1} \mathrm{H}$ NMR $\left(\mathrm{CDCl}_{3}, \mathrm{ppm}\right) ; \delta: 4.68(\mathrm{~d}, \mathrm{H}-5, \mathrm{~J}=8.4 \mathrm{~Hz}), 5.57$ (s, H-3, H-4), 6.03 (s, 1H, 3" furan), 6.18 (s, 1H, 4" furan), $6.73(\mathrm{~d}, 1 \mathrm{H}, \mathrm{J}=6.4 \mathrm{~Hz}, 5$ ' furan), 6.96-8.03 (m, 14H Aromatic protons). ${ }^{13} \mathrm{C}$ NMR $\left(\mathrm{CDCl}_{3}, \mathrm{ppm}\right) ; \delta: 196.6(\mathrm{C}=\mathrm{O}), 180.5(\mathrm{C}=\mathrm{O}), 153.8(\mathrm{C}-\mathrm{O}$, furan $), 72.3$ (C-2), 57.0 (C-3), 54.4 (C-5), 52.4 (C-4), 108.2 (3" carbon), 109.7 (4" carbon), 110.2 (5" carbon), $114.9,115.1,116.1,116.3,121.8,123.2$, 123.9, 127.7, 128.1, 128.3, 128.5, 128.6, 129.1, 129.3, 129.4, 129.6, 130.1, 130.3, 130.4, 132.9, 133.0, 133.2, 137.2, 138.1, 140.7, 142.4, 143.6 (Aromatic carbon). 


\section{3'-benzoyl-4'-(4-chlorophenyl)-5' -(furan-2-yl)spiro[indoline-3,2'-pyrrolidin]-2-one (4e)}

M.F.: $\mathrm{C}_{28} \mathrm{H}_{21} \mathrm{ClN}_{2} \mathrm{O}_{3}$, m.p. $\left({ }^{0} \mathrm{C}\right): 240-243$, Yield (\%): 81, IR (Neat, $\mathrm{cm}^{-1} ; 1710.00,1701.62(\mathrm{C}=\mathrm{O})$, 3260.52, $3109.01(\mathrm{NH}) .{ }^{1} \mathrm{H}$ NMR $\left(\mathrm{CDCl}_{3}, \mathrm{ppm}\right) ; \delta: 4.68$ (d, H-5, J=12.4 Hz), 5.57 (s, H-3, H-4), $6.03\left(\mathrm{~d}, \mathrm{~J}=3.2 \mathrm{~Hz}, 1 \mathrm{H}, 3^{\prime \prime}\right.$ furan), 6.19 (s, 1H, 4" furan), 6.96 (d, 1H, J=8.8 Hz, 5" furan), 7.25-8.03 (m, 14H Aromatic protons). ${ }^{13} \mathrm{C}$ NMR $\left(\mathrm{CDCl}_{3}, \mathrm{ppm}\right) ; \delta: 190.7(\mathrm{C}=\mathrm{O}), 179.5(\mathrm{C}=\mathrm{O}), 153.8(\mathrm{C}-\mathrm{O}$, furan), 72.4 (C-2), 58.5 (C-3), 57.1 (C-5), 55.2 (C-4), 108.8 (3" carbon), 109.7 (4" carbon), 110.3 (5" carbon), 122.1, 127.8, 127.9, 128.0, 128.1, 128.3, 128.6, 130.6, 132.8, 134.9, 138.2, 142.3, 144.9 (Aromatic carbon).

\section{3'-benzoyl-4'-(4-bromophenyl)-5'-(furan-2-yl)spiro[indoline-3,2'-pyrrolidin]-2-one (4f)}

M.F.: $\mathrm{C}_{28} \mathrm{H}_{21} \mathrm{BrN}_{2} \mathrm{O}_{3}$, m.p. $\left({ }^{0} \mathrm{C}\right)$ : 254-257, Yield(\%): 73, IR (Neat, $\left.\mathrm{cm}^{-1}\right) ; 1710.60,1701.92(\mathrm{C}=\mathrm{O})$, 3248.03, 3104. $00(\mathrm{NH}) .{ }^{1} \mathrm{H}$ NMR $\left(\mathrm{CDCl}_{3}, \mathrm{ppm}\right) ; \delta:{ }^{1} \mathrm{H} \mathrm{NMR}\left(\mathrm{CDCl}_{3}, \mathrm{ppm}\right) ; \delta: 4.62(\mathrm{~d}, \mathrm{H}-5, \mathrm{~J}=12.4$ Hz), 5.56 (s, H-3, H-4), 6.03 (d, J=3.2 Hz, 1H, 3" furan), 6.13 (s, 1H, 4" furan), 6.86 (d, 1H, J= 8.8 Hz, $5^{\prime \prime}$ furan), 6.87-7.92 (m, 14H Aromatic protons). ${ }^{13} \mathrm{C} \mathrm{NMR}\left(\mathrm{CDCl}_{3}, \mathrm{ppm}\right) ; \delta: 200.1(\mathrm{C}=\mathrm{O}), 196.5$ $(\mathrm{C}=\mathrm{O}), 153.7$ (C-O, furan), 72.1 (C-2), 57.0 (C-3), 54.6 (C-5), 52.4 (C-4), 108.2 (3" carbon), 109.8 (4" carbon), 110.3 (5" carbon), 121.5, 123.3, 123.9, 127.7, 128.1, 128.3, 128.5, 128.6, 128.7, 128.7, 129.5, 129.6, 129.8, 129.9, 131.0, 131.3, 131.8, 133.2, 133.9, 140.7, 142.4 (Aromatic carbon).

3'-benzoyl-4'- (4-(dimethylamino)phenyl)-5'-(furan-2- yl)spiro[indoline-3,2'-pyrrolidin]-2-one $(4 \mathrm{~g})$

M.F.: $\mathrm{C}_{30} \mathrm{H}_{27} \mathrm{~N}_{3} \mathrm{O}_{3}$, m.p. $\left({ }^{0} \mathrm{C}\right)$ : 251-253, Yield(\%): 71, IR (Neat, $\left.\mathrm{cm}^{-1}\right) ; 1711.70,1700.22(\mathrm{C}=\mathrm{O})$, 3251.50, 3100. $80(\mathrm{NH}) .{ }^{1} \mathrm{H}$ NMR $\left(\mathrm{CDCl}_{3}, \mathrm{ppm}\right) ; \delta: 3.01\left(\mathrm{~s}, 6-\mathrm{H},(\mathrm{NCH} 3)_{2}, 4.68(\mathrm{~d}, \mathrm{H}-5, \mathrm{~J}=12.4\right.$ Hz), 5.57 (s, H-3, H-4), 6.03 (d, J=3.2 Hz, 1H, 3" furan), 6.18 (s, 1H, 4" furan), 6.73 (d, 1H, J= 8.8 $\mathrm{Hz}$, 5" furan), 6.96-8.03 (m, 14H Aromatic protons). ${ }^{13} \mathrm{C} \mathrm{NMR}\left(\mathrm{CDCl}_{3}, \mathrm{ppm}\right) ; \delta: 196.4(\mathrm{C}=\mathrm{O})$, $180.9(\mathrm{C}=\mathrm{O}), 158.7\left(\mathrm{C}-\mathrm{O}\right.$, furan), $72.4(\mathrm{C}-2), 57.8(\mathrm{C}-3), 54.4(\mathrm{C}-5), 52.4(\mathrm{C}-4), 62.3 \quad\left(\mathrm{~N}^{-\mathrm{CH}_{3}}\right)_{2}$, 107.9 (3" carbon), 109.8 (4" carbon), 110.3 (5" carbon), 121.5, 123.3, 123.9, 127.7, 128.1, 128.3, $128.5,128.6,128.7,128.7,129.5,129.6,129.8,129.9,131.0,131.3,131.8,133.2,133.9,140.7$, 142.4 (Aromatic and ipso carbon).

\section{Conclusions}

3'-benzoyl-5'-(furan-2-yl)-4'-phenylspiro[indoline-3,2'-pyrrolidin]-2-one derivatives (4a-g) have been synthesized and characterized by IR, ${ }^{1} \mathrm{H}$ and ${ }^{13} \mathrm{C}$ NMR spectral techniques. In addition, two-dimensional NMR spectra of ${ }^{1} \mathrm{H}^{-13} \mathrm{C}$ COSY spectrum have been recorded for 4a. Molecular docking studies were carried out to investigate the precise binding site of ligand on protein. The compound 4a showed very high ligand pose energy $(-13.45 \mathrm{kcal} / \mathrm{mol})$ compared to glucosamine-6phosphate $(-6.31 \mathrm{kcal} / \mathrm{mol})$. The best ligand pose energy of compound $\mathbf{4 b}$ is $-18.06 \mathrm{kcal} / \mathrm{mol}$ whereas the standard drug molecule is $-10.47 \mathrm{kcal} / \mathrm{mol}$. In this binding mode, compound $\mathbf{4 b}$ was attractively bound to 3LD6 via Vander Waals interactions. The in vitro antimicrobial activity data of compounds 4a, 4b and $\mathbf{4 g}$ displayed the highest activity (MIC $12.5 \mu \mathrm{g} / \mathrm{ml}^{-1}$ against Klepsilae pneumonia and in the case of B. Cereus, compounds $4 \mathbf{a}, \mathbf{4 b}, \mathbf{4 c}$ and $\mathbf{4 f}$ were found to be the most active derivative in vitro with a MIC of $12.5,25,25$ and $12.5 \mu \mathrm{g} / \mathrm{ml}$, respectively. Compound $4 \mathbf{b}$ $(\mathrm{MIC}=3.125 \mu \mathrm{g} / \mathrm{ml})$ exhibited superior antifungal activity against $C$. albicans and $A$. niger related to other fungal strains with compared to standard amphotericin B.

\section{Conflict of Interest}

The authors declare that there is no conflict of interest.

\section{Acknowledgements}

The authors K. Krishnasamy and D. Rajaraman thankful to Sri Ramachandra Medical College, Chennai for carrying out the anticancer activities. 


\section{References}

[1] A. Kaur, M. Kaur, B. Singh, One-pot Regioselective Synthesis of Novel 1-N-Methylspiro[2,3'] Multicomponent 1,3-Dipolar Cycloaddition Reaction of Azomethine Ylide, J. Heterocycl. Chem. 52(3) (2014) 827-833.

[2] E. Ruijter, R. Scheffelaar, R.V. Orru, Multicomponent reaction design in the quest for molecular complexity and diversity, Angew. Chem. Int. Ed. 50(28) (2011) 6234-6246.

[3] K.A. Ohemeng et al., DNA gyrase inhibitory and antibacterial activity of some flavones (1), Bioorg. Med. Chem. Lett. 3 (1993) 225-230.

[4] K. Ding et al., Structure-based design of spiro-oxindoles as potent, specific small-molecule inhibitors of the MDM2- p53 interaction, J. Med. Chem. 49(12) (2006) 3432-3435.

[5] S.M. Rajesh et al., Antimycobacterial activity of spirooxindolo-pyrrolidine, pyrrolizine and pyrrolothiazole hybrids obtained by a three-component regio-and stereoselective 1, 3-dipolar cycloaddition, Med. Chem. Commun. 2(7) (2011) 626-630.

[6] C. Peng et al., Additive-assisted regioselective 1,3-dipolar cycloaddition of azomethine ylides with benzylideneacetone, Beilstein J. Org. Chem. 10 (2014) 352-360.

[7] O. Tsuge, S. Kanemasa, M. Yoshioka, Lithium bromide-triethylamine induced cycloaddition of $\mathrm{N}$-alkylidene 2-amino esters and amides to electron-deficient olefins with high regio-and stereoselectivity, J. Org. Chem. 53(7) (1988) 1384-1391.

[8] R.R. Kumar, S. Perumal, Sacrificial azomethine ylide cycloaddition controlled chemoselective nitrile oxide cycloaddition to 1-methyl-3, 5-bis [(E)-arylmethylidene] tetrahydro-4 $(1 \mathrm{H})$-pyridinones: formation of mono-spiro-isoxazolines, Tetrahedron. 63(49) (2007) 12220-12231.

[9] J. Jayashankaran et al., A regioselective synthesis of dispiro [oxindole-cyclohexanone] pyrrolidines and dispiro [oxindole-hexahydroindazole] pyrrolidines by sequential 1, 3-dipolar cycloaddition and annulation through a microwave induced solvent-free approach, Tetrahedron. 61(23) (2005) 5595-5598.

[10] K. Anjandeep et al., Synthesis and biological activity of 4-aryl-3-benzoyl-5-phenylspiro [pyrrolidine-2.3'-indolin]-2'-one derivatives as novel potent inhibitors of advanced glycation end product, E. J. Med Chem. 79 (2014) 282-289.

[11] L.M. Stanley, M.P. Sibi, Enantioselective copper-catalyzed 1, 3-dipolar cycloadditions, Chem. Rev. 108(8) (2008) 2887-2902.

[12] G. Chen et al., Spiro[pyrrolidine-2,3'-oxindole] derivatives synthesized by novel regionselective 1,3-dipolar cycloadditions, Molecular Diversity. 16 (2012) 151-156.

[13] S.M. Rajesh et al., Antimycobacterial activity of spirooxindolo-pyrrolidine, pyrrolizine and pyrrolothiazole hybrids obtained by a three-component regio-and stereoselective 1, 3-dipolar cycloaddition, Med. Chem. Commun. 2 (2011) 626-630.

[14] L. Tian et al., Organocatalytic asymmetric multicomponent cascade reaction via 1, 3-proton shift and [3+2] cycloaddition: an efficient strategy for the synthesis of oxindole derivatives, Chem. Commun. 49(65) (2013) 7213-7215.

[15] R.D. Carpenter, K.S. Lam, M.J. Kurth, Microwave-Mediated Heterocyclization to Benzimidazo[2,1-b]quinazolin-12(5H)-ones, J. Org. Chem. 72(1) (2007) 284-287. 